\title{
Candesartan targeting of angiotensin II type 1 receptor demonstrates benefits for hypertension in pregnancy via the NF-kB signaling pathway
}

\author{
$\mathrm{XUDONG}_{\mathrm{ZHAO}}{ }^{1,2}$ and XIETONG WANG ${ }^{1,2}$ \\ ${ }^{1}$ Department of Gynecology and Obstetrics, Shandong Provincial Hospital Affiliated to Shandong University, \\ Jinan, Shandong 250021; ${ }^{2}$ Department of Gynecology and Obstetrics, The Central Hospital of Taian City, \\ Taian, Shandong 271000, P.R. China
}

Received September 12, 2016; Accepted December 13, 2017

DOI: $10.3892 / \mathrm{mmr} .2018 .9070$

\begin{abstract}
Hypertensive disorders may be a complication of pregnancy and are characterized by the high blood pressure. Evidence suggests that alterations in the renin-angiotensin-aldosterone system and the sympathetic nervous system are associated with gestational hypertension. Angiotensin II type 1 receptor (Ang-IITR) is a potential target in the progression of gestational hypertension. Candesartan is selective Ang-IITR antagonist that may act against vasoconstriction and reduces peripheral vascular resistance. The aim of the present study was to evaluate the efficacy of Candesartan and the underlying molecular mechanism of the nuclear factor- $\kappa \mathrm{B}(\mathrm{NF}-\kappa \mathrm{B})$ signaling pathway in the progression of gestational hypertension in a mouse model. Expression and activity of Ang-IITR was evaluated in a mouse model of gestational hypertension prior to and post-treatment of Candesartan both in vitro and in vivo. It was determined whether Candesartan treatment reduces higher blood pressure activated the renal renin-angiotensin system and a prognostic marker, soluble endoglin, and its associated gene in mice with gestational hypertension. Angiotensin-converting enzyme plasma levels and activity were also evaluated in the present study. Cytoplasmic and nuclear immunostaining of NF- $\mathrm{KB}$ and associated proteins transforming growth factor $\beta$ (TGF- $\beta$ ) and endoglin was enhanced in vascular endothelial cells and mice with gestational hypertension. Soluble fms-like tyrosine kinase 1 (sFlt-1), insulin resistance homeostasis model assessment score and associated cardiovascular risk factors also were measured. Results demonstrated that
\end{abstract}

Correspondence to: Professor Xietong Wang, Department of Gynecology and Obstetrics, Shandong Provincial Hospital Affiliated to Shandong University, 324 Jingwu Weiqi Road, Jinan, Shandong 250021, P.R. China

E-mail: wangxietongsd@163.com

Key words: Candesartan, gestational hypertension, angiotensin, nuclear factor $-\kappa \mathrm{B}$ angiotensin and Ang-IITR expression levels were upregulated in mice with gestational hypertension and were downregulated by Candesartan treatment. Renal renin-angiotensin and soluble endoglin were also improved in mice in the Candesartan-treated group. In addition, Candesartan treatment enhanced NF- $\kappa$ B activity, as well as TGF- $\beta$ and vascular endothelial growth factor expression which led to improved levels of sFlt-1, insulin resistance homeostasis and associated cardiovascular risk factors. Gestational hypertension was markedly improved by treatment of Candesartan compared with the control. In conclusion, the findings of the present study suggested that the NF-kB signaling pathway may be involved in with Candesartan-mediated Ang-IITR for the treatment of gestational hypertension.

\section{Introduction}

Gestational hypertension is a complication that specifically occurs in late pregnancy, and includes gestational hypertension, preeclampsia, eclampsia and chronic hypertension $(1,2)$. A clinical investigation suggested that hypertensive disorder is a complication during pregnancy, is a common pregnancy-associated disease and is becoming increasingly present worldwide (3). However, the etiology of gestational hypertension is yet to be clearly investigated. Currently, insulin resistance, renin-angiotensin-aldosterone system (RAS) dysfunction, inflammation, obesity-induced interaction of neurohumoral and renal mechanisms are considered to be contributing factors of gestational hypertension $(4,5)$. In addition, genetic factors that contribute to gestational hypertension have been well documented in a previous study (6). Furthermore, gestational hypertension seriously affects the life expectancy of the mother and fetus in the clinical setting $(7,8)$. Gestational hypertension is one of the leading causes of maternal, fetal and neonatal morbidity and mortality $(4,9)$. Reports have suggested that the incidence rate of gestational hypertension is approxinately $7-12 \%$ in China, presenting a higher than the average incidence throughout the world (10).

Evidence has revealed that clinical assisted reproductive technology treatment, including artificial insemination and ovulation induction, may increase the incidence of gestational 
hypertension and preeclampsia (11). In addition, there are a large number of factors that may induce gestational hypertension, and have been found to serve a role in the etiology of these hypertensive disorders, including work stress, depression and anxiety $(12,13)$. Reports also have indicated that angiotensin II type 1 receptor (Ang-IITR), vasodilation converting enzyme (VCE) and $\alpha$-1A adrenergic receptor ( $\alpha$-ADR) serve crucial roles in the process of gestational hypertension and may be potential targets for the treatment of patients with gestational hypertension in clinical $(3,12,13)$. Therefore, a large number of drugs targeting Ang-IITR were introduced and their therapeutic effects for the treatment of gestational hypertension were evaluated.

Ang-IITR has been demonstrated to be a potential target in the progression of gestational hypertension and higher expression levels of this receptor exist in vascular endothelial cells in patients with gestational hypertension, compared with healthy pregnant women $(14,15)$. Antihypertensive agents targeting Ang-IITR are the most common used drugs for remission patients with gestational hypertension $(16,17)$. Candesartan $\left(\mathrm{C}_{24} \mathrm{H}_{20} \mathrm{~N}_{6} \mathrm{O}_{3}\right)$, is an antihypertensive drug, and is a selective Ang-IITR antagonist that acts by reducing peripheral vascular resistance and vasoconstriction $(18,19)$. Candesartan is used to treat hypertension and prevents the constriction (narrowing) of blood vessels, including veins and arteries. In addition, fibrinolysis and insulin sensitivity was improved by treatment with Imidapril and Candesartan in patients with hypertension (20). The effect of Candesartan treatment on lipid metabolism in patients with hypertension has also been investigated in a retrospective longitudinal survey (21). However, the efficacy of Candesartan for gestational hypertension has not been previously studied.

In the present study, the therapeutic effects of Candesartan on gestational hypertension in a mouse model was investigated, in addition to the underlying molecular mechanisms by which it contributes to attenuating gestational hypertension induced by homocysteine. The aim of the present study was to characterize alterations in Ang-IITR, soluble fms-like tyrosine kinase 1 (sFlt-1), insulin resistance homeostasis model assessment score and associated cardiovascular risk factors in mice with gestational hypertension after treatment with Candesartan. NF- $\kappa \mathrm{B}$ activation and nuclear factor NF- $\kappa \mathrm{B}$ p65 subunit (p65), inhibitor of NF- $\kappa$ B kinase subunit $\beta$ (IKK- $\beta$ ) and $N F-\kappa B$ inhibitor $\alpha(\mathrm{I} \kappa \mathrm{B} \alpha)$ expression levels were also investigated in vascular endothelial cells in mice treated by Candesartan.

\section{Materials and methods}

Ethics statement. The present study was carried out in strict accordance with the recommendations in the Guide for Shandong Provincial Hospital affiliated to Shandong University. All surgery and euthanasia were performed to minimize suffering. This study was approved by the ethics committee of Shangdong University and Taian City Central Hospital (Jinan, China).

Cell culture and reagents. Vascular endothelial cells were isolated from experimental mice and cultured in Minimum Essential media (Merck KGaA, Darmstadt, Germany) supplemented with $10 \%$ fetal bovine serum (Invitrogen; Thermo Fisher Scientific, Inc., Waltham, MA, USA). Vascular endothelial cells were cultured at $37^{\circ} \mathrm{C}$ in a humidified atmosphere of $5 \% \mathrm{CO}_{2}$. Cells were treated with Candesartan and/or NF- $\kappa$ B activity inhibitor JSH23 (Sigma-Aldrich; Merck $\mathrm{KGaA}$ ) for $12 \mathrm{~h}$ at $37^{\circ} \mathrm{C}$.

Western blot analysis. Vascular endothelial cells were homogenized in radioimmunoprecipitation assay lysis buffer (Sigma-Aldrich; Merck KGaA) containing protease-inhibitor and centrifuged at $6,000 \mathrm{x}$ g at $4^{\circ} \mathrm{C}$ for $10 \mathrm{~min}$. The resulting supernatant was used for analysis of proteins. Protein concentration was determined with a bicinchoninic acid protein assay kit. Protein (10 $\mu \mathrm{g} /$ lane) was separated by $12.5 \%$ SDS-PAGE and subsequently transferred onto polyvinylidene fluoride membranes as previously described (22). For western blotting, membranes were incubated with the following primary antibodies for $12 \mathrm{~h}$ at $4^{\circ} \mathrm{C}$ : Superoxide dismutase (SOD; 1:1,000; cat. no. A91960Hu01; Shanghai Wuqi Biotechnology Co., Ltd., Shanghai, China) sFlt-1 (1:1,000; cat. no. ab230516), tumor necrosis factor $\alpha$ (TNF- $\alpha ; 1: 1,000$; cat. no. ab6671), interleukin-2 (1:1,000; cat. no. ab80780), reactive oxygen species (ROS; 1:1,000; cat. no. ab191522), transcription factor p65 (1:1,000; cat. no. ab16502), inhibitor of nuclear factor $\kappa-\mathrm{B}$ kinase subunit $\beta$ (Ikk- $\beta$; $1: 1,000$; cat. no. ab17870), NF- $\kappa \mathrm{B}$ inhibitor $\alpha(\mathrm{I} \kappa \mathrm{B} \alpha ; 1: 1,000$; cat. no. ab16502) and $\beta$-actin (1:1,000; cat. no. ab8227; all Abcam, Cambridge, MA, USA) were added following blocking in $5 \%$ skimmed milk for $60 \mathrm{~min}$ at $37^{\circ} \mathrm{C}$. After washing with PBS three times, horseradish peroxidase-conjugated goat anti-rabbit IgG monoclonal secondary antibodies (1:2,000; cat. no. PV-6001; OriGene Technologies, Inc., Beijing, China) were added for $2 \mathrm{~h}$ at $37^{\circ} \mathrm{C}$. The results were visualized with chemiluminescence substrate (Roche Diagnostics, Basel, Switzerland). Band density was analyzed by Quantity One software (version 4.62; Bio-Rad Laboratories, Inc., Hercules, CA, USA).

Animal study. Female C57BL/6 mice (aged 8 weeks; 25-30 g) were purchased from Jackson Laboratory (Ben Harbor, ME, USA) and housed in a $12 \mathrm{~h}$ light-dark cycle at $23 \pm 1^{\circ} \mathrm{C}$ with a relative humidity of $50 \pm 5 \%$. All mice had free to access food and water. The mouse model of gestational hypertension was established according to previous studies $(23,24)$. Mice with gestational hypertension were divided into two groups and received treatment with Candesartan $(0.2 \mathrm{mg} / \mathrm{kg})$ or with PBS as a control once daily for a total of 7 days.

Reverse transcription-quantitative polymerase chain reaction $(R T-q P C R)$. Total RNA was extracted from vascular endothelial cells by using an RNAeasy Mini kit (Qiagen $\mathrm{GmbH}$, Hilden, Germany). RNA was reversed to cDNA using a one-step reverse transcription kit (Thermo Fisher Scientific, Inc.). Vascular endothelial growth factor (VEGF), transforming growth factor $\beta$ (TGF- $\beta$ ), angiopoietin-1 (Ang-1), placental growth factor (PLGF), angiotensin, Ang-IITR, cytokine-induced neutrophil chemoattractant 1 (CINC-1), lipopolysaccharide induced CXC chemokine (LIX), monokine, $\alpha$-ADR expression levels in vascular endothelial cells were determined by RT-qPCR with $\beta$-actin as an endogenous 
Table I. Primer sequences used for reverse transcription-quantitative polymerase chain reaction.

\begin{tabular}{lll}
\hline Gene name & \multicolumn{1}{c}{ Reverse primer } & \multicolumn{1}{c}{ Forward primer } \\
\hline Angiotensin & 5'-GCAAGCGCAAGACCACTAAC-3' & 5'-GCCGCTGTAATCCATCATGC -3' \\
Ang-IITR & 5'-AAGAGAGCTTCCGTAAGGCG-3' & 5'-GCATCCTCTTCAGTTACGTCC -3' \\
VEGF & 5'-TTGCTGCTCTACCTCCAC-3' & 5'-AATGCTTTCTCCGCTCTG-3' \\
TGF- $\beta$ & 5'-CCCCTGGAAAGGGCTCAACAC-3' & 5'-TCCAACCCAGGTCCTTCCTAAAGTC-3' \\
Ang-1 & 5'-GAAGGAAACCGAGCCTATTCAC-3' & 5'-CCACAAGCATCAAACCACCA-3' \\
PLGF & 5'-GTTCAGCCCATCCTGTGTCT -3' \\
CINC-1 & 5'-GAAGATAGATTGCACCGATG-3' & 5'-CTTCATCTTCTCCCGCAGAG -3' \\
LIX & 5'-GCATCTCATCTGTTACAGC-3' & 5'-CATAGCCTCTCACACATTTC-3' \\
Monokine & 5'-AGGCCTCCTGGGCTTCAT-3' & 5'-GCAAGCGCAAGACCACTAAC-3' \\
$\alpha-A D R$ & 5'-AAACCTGTCCAACTACCTC-3' & 5'-GGAGTAGAAGTCCCGCAGGAT-3' \\
$\beta$-actin & 5'-CGGAGTCAACGGATTTGGTC-3' & 5'- TAATCCTCGTCTCCTTCC -3' \\
\end{tabular}

control (25) (Invitrogen; Thermo Fisher Scientific, Inc.). All forward and reverse primers were synthesized by Invitrogen; Thermo Fisher Scientific, Inc. (Table I). The thermocycling conditions were as follows: Initial denaturation at $94^{\circ} \mathrm{C}$ for $2 \mathrm{~min}$, followed by 35 cycles of $95^{\circ} \mathrm{C}$ for $30 \mathrm{sec}, 54^{\circ} \mathrm{C}$ for $30 \mathrm{sec}$ and $72^{\circ} \mathrm{C}$ for $10 \mathrm{~min}$. The reaction volume $(50 \mu \mathrm{l})$ contained $50 \mathrm{ng}$ genomic cDNA, $200 \mu \mathrm{M}$ dNTPs, $200 \mu \mathrm{M}$ primers, 2.5 U Taq DNA polymerase (Thermo Fisher Scientific, Inc.) and 2.5 U SYBR-Green (Thermo Fisher Scientific, Inc.). Relative mRNA expression levels were calculated by the $2^{-\Delta \Delta \mathrm{Cq}}$ method (26). The results are expressed as the $\mathrm{n}$-fold way compared to control.

Immunohistochemical staining. Immunohistochemical staining was performed using the avidin-biotin-peroxidase technique. Paraffin-embedded tumor tissue sections $(5 \mu \mathrm{m})$ were fixed with $10 \%$ paraformaldehyde for $2 \mathrm{~h}$ at $37^{\circ} \mathrm{C}$ were prepared and subsequently deparaffinized in xylene and washed in PBS with Tween-20 (1\%) three times at room temperature, followed by epitope retrieval using Tris-EDTA buffer solution ( $\mathrm{pH}$ 9.0; Sigma-Aldrich; Merck KGaA; cat. no. SRE0063) for $60 \mathrm{~min}$ at $65^{\circ} \mathrm{C}$. The paraffin sections were subjected to hydrogen peroxide (3\%) for 10-15 min, and were subsequently blocked with $5 \%$ bovine serum albumin (Sigma-Aldrich; Merck KGaA) for $10-15 \mathrm{~min}$ at $37^{\circ} \mathrm{C}$. Finally, the sections were incubated with rabbit anti-mouse p65 (1:1,000; cat. no. ab16502), Ikk- $\beta$ (1:1,000; cat. no. ab17870), $\mathrm{I} \kappa \mathrm{B} \alpha\left(1: 1,000\right.$; cat. no. ab16502; all Abcam) t $4^{\circ} \mathrm{C}$ for $12 \mathrm{~h}$. All sections were washed three times and incubated with Alexa Fluor ${ }^{\circledR} 488$-conjugated goat anti-rabbit IgG secondary antibody (1:1,000; cat. no. ab150077; Abcam) for $1 \mathrm{~h}$ at $37^{\circ} \mathrm{C}$ and were observed in six random fields of view under a fluorescence microscope at $x 40$ magnification.

Enzyme-linked immunosorbent assay (ELISA). Plasma concentration levels of angiotensin, VCE and $\alpha$-ADR from mice with gestational hypertension were detected by ELISA after receiving treatment with Candesartan, using commercialized ELISA kits for ACE (cat. no. DL-ACE2-Mu), $\alpha$-ADR (cat. no. KL-EL001391SH; both Shanghai Kanglang Biotechnology Co., Ltd., Shanghai, China), according to the manufacturer's protocol. The absorbance was measured at a wavelength of $450 \mathrm{~nm}$ on an ELISA plate reader.

Analysis of Th1/Th2. Plasma concentration levels Th1/Th2 were measured using Th1/Th2 kit (LHC0015M, Thermo Fisher Scientific, Inc.) according to the manufacturer's protocol.

Activity of $N F-\kappa B$. Activity of $\mathrm{NF}-\kappa \mathrm{B}$ in vascular endothelial cells from healthy mice and mice with gestational hypertension was analyzed after receiving treatment with Candesartan. The activity of NF- $\kappa \mathrm{B}$ was determined with the NF- $\kappa \mathrm{B}$ p65 Transcription Factor Assay Kit (cat. no. 10007889; Shenzen Xinbo Sheng Biological Technology Co., Ltd., Shenzen, China) according to the manufacturer's instructions.

Statistical analysis. All data are presented as mean \pm standard error of three replicates within the same experiment and performed using GraphPad Prism software 5.0 (GraphPad Software, Inc., La Jolla, CA, USA). Statistical differences between experimental groups were analyzed by Student's t-test or a one-way analysis of variance followed by Tukey's post-hoc test. $\mathrm{P}<0.05$ was considered to indicate a statistically significant difference.

\section{Results}

Effects of Candesartan treatment on expression of Ang-IITR in vascular endothelial cells. To assess the impact of Candesartan on angiotensin release and Ang-IITR expression in a gestational hypertension model system, isolated endothelial cells were incubated with Candesartan. Angiotensin expression levels were upregulated in control vascular endothelial cells, whereas Candesartan significantly inhibited angiotensin release compared with control mice; there was no significant compared with healthy mice (Fig. 1A). In vitro assays indicated that homocysteine also induced angiotensin release compared with the control group, whereas Candesartan treatment inhibited angiotensin release compared with the control group (Fig. 1B). In addition, Ang-IITR expression levels (Fig. 1C) and angiotensin plasma concentration levels (Fig. 1D) were upregulated in control group compared with the healthy 
A

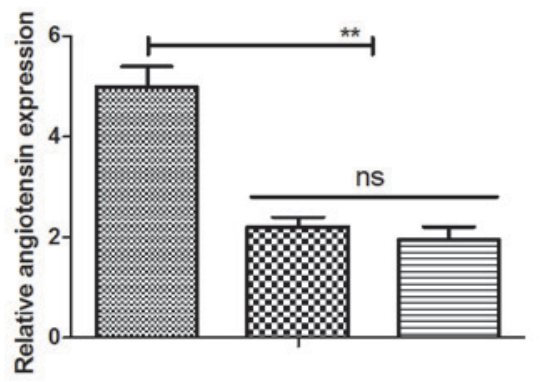

C

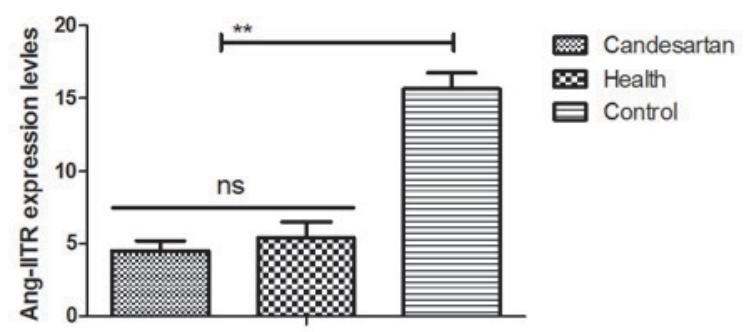

$\mathbf{E}$

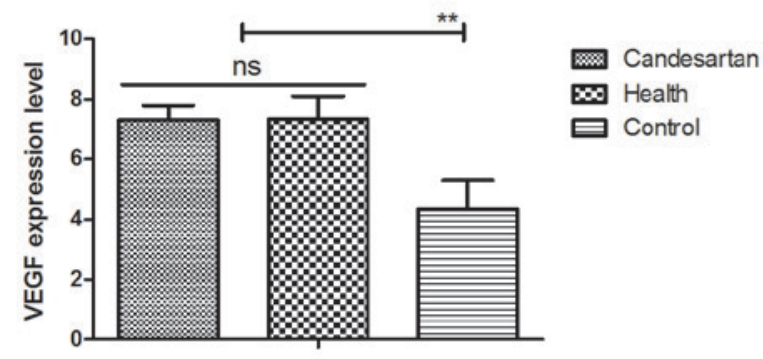

G

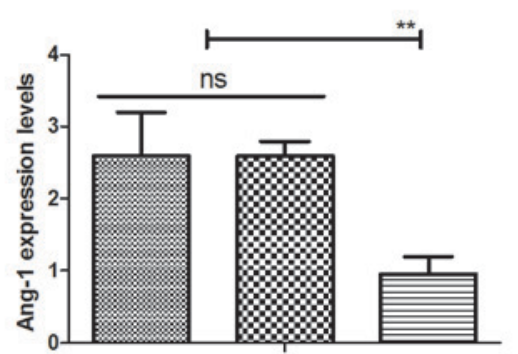

B

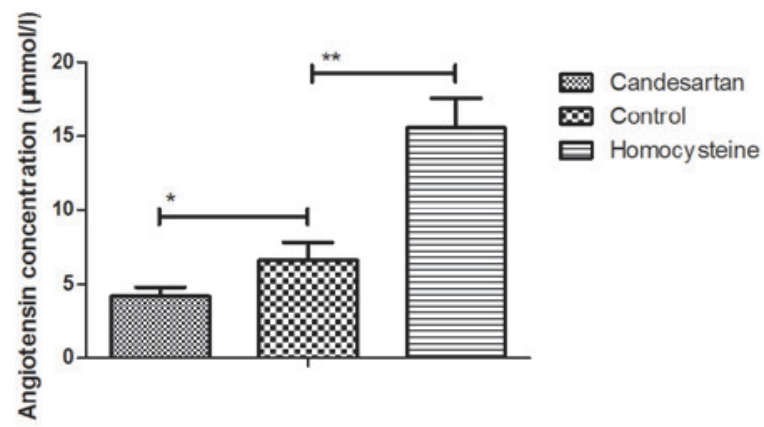

D

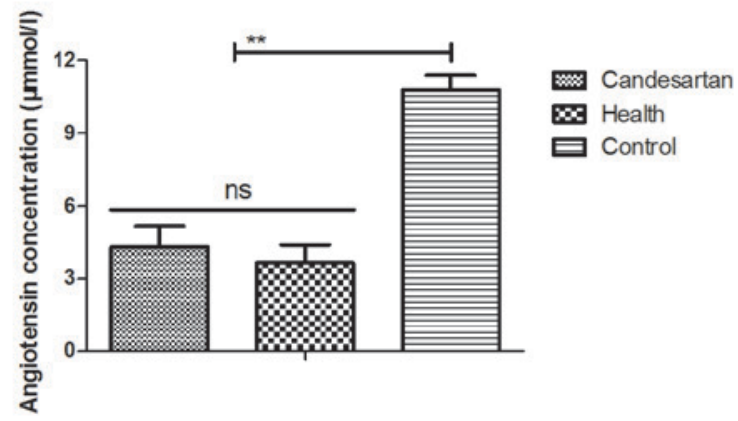

$\mathbf{F}$

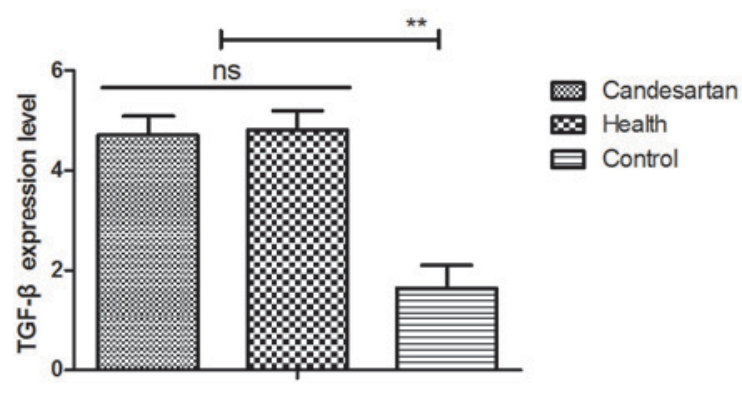

H

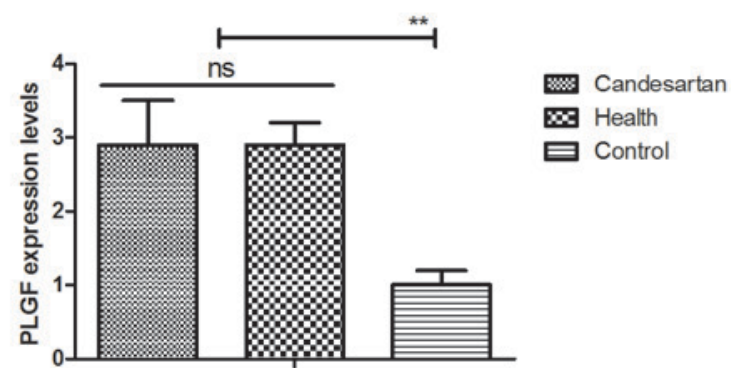

Figure 1. Effects of Candesartan on Ang-IITR and expression levels of hypertension-related proteins in vascular endothelial cells. (A) Angiotensin expression levels in control, healthy or Candesartan-treated vascular endothelial cells. (B) Angiotensin release in vascular endothelial cells after treatment with homocysteine or Candesartan. (C) Ang-IITR expression levels and (D) angiotensin plasma concentration levels in control or Candesartan-treated mice with gestational hypertension. Analysis of (E) VEGF, (F) TGF- $\beta$, (G) Ang-1 and (H) PLGF expression levels in control, healthy or Candesartan-treated vascular endothelial cells. The data are presented as the mean \pm standard error. ${ }^{*} \mathrm{P}<0.05$ and ${ }^{* *} \mathrm{P}<0.01$ vs. control. ns, no significant difference; VEGF, vascular endothelial growth factor; TGF- $\beta$, transforming growth factor- $\beta$; Ang-1, angiopoietin-1; PLGF, placental growth factor; Ang-IITR, angiotensin II type 1 receptor.

group and were downregulated after Candesartan treatment in vivo compared with the control group. Furthermore, we analyzed expression levels of hypertension-related proteins.
As demonstrated in Fig. 1E-H, VEGF, TGF- $\beta$, Ang-1 and PLGF expression levels were upregulated by Candesartan compared with the control group. Taken together, these results 
suggested that Candesartan treatment may be beneficial for the downregulation of angiotensin release and Ang-IITR expression in vascular endothelial cells and mice with gestational hypertension induced by homocysteine.

Candesartan treatment markedly improves sFlt-1, insulin resistance, and cardiovascular risk factors. Gestational hypertension is characterized by widespread endothelial cell dysfunction, the progressive elevation of insulin resistance and higher expression of cardiovascular risk factors (27). Western blot analyses of sFlt-1 revealed that Candesartan treatment significantly decreased sFlt-1 expression levels compared with control vascular endothelial cells (Fig. 2A). Insulin resistance of mice was significantly improved in mice with gestational hypertension after treatment with Candesartan compared with the control group (Fig. 2B). In addition, renal prorenin receptor expression levels were also downregulated by Candesartan compared with the control group (Fig. 2C). Furthermore, cardiovascular risk factors including inflammation and oxidative stress were studied in the vascular endothelial cells after treatment with Candesartan. As demonstrated in Fig. 2D-F, tumor necrosis factor- $\alpha$ and interleukin- 2 expression and the balance of Th1/Th2 was downregulated by Candesartan compared with the control group, in the serum of mice with gestational hypertension. Western blot analysis of oxidative stress demonstrated that expression levels of SOD (Fig. 1G) and ROS (Fig. 1H) were downregulated by Candesartan compared with control vascular endothelial cells. Taken together, these results suggested that Candesartan treatment markedly improved sFlt-1, insulin resistance and cardiovascular risk factors.

Candesartan regulates soluble endoglin via the $N F-\kappa B$ signaling pathway. To analyze the mechanism of Candesartan-mediated benefits for gestational hypertension, the NF- $\kappa \mathrm{B}$ signaling pathway was investigated. Soluble endoglin expression was analyzed in vascular endothelial cells. As demonstrated in Fig. 3A, endoglin expression was downregulated by Candesartan compared with the control. Cytokine mRNA expressions levels of CINC-1 (Fig. 3B), LIX (Fig. 3C) and monokine (Fig. 3D) were decreased after treatment with Candesartan compared with the control. In addition, it was observed that p65, IKK- $\beta$ and $\mathrm{I} \kappa \mathrm{B} \alpha$ expression levels were upregulated by Candesartan in vascular endothelial cells, compared with the control (Fig. 3E). $\mathrm{NF}-\kappa \mathrm{B}$ activity was upregulated by Candesartan in vascular endothelial cells compared with the control (Fig. 3F). Inhibition of NF- $\kappa \mathrm{B}$ activity by JSH23 reversed Candesartan-mediated reduction of sFlt-1 and endoglin expression levels (Fig. 3G, $\mathrm{H})$. Taken together, the data suggested that Candesartan may mediate gestational hypertension via the endoglin-mediated $\mathrm{NF}-\kappa \mathrm{B}$ signaling pathway.

Analysis of the efficacy of Candesartan treatment on mice with gestational hypertension induced by homocysteine. To determine the therapeutic effects of Candesartan for gestational hypertension, a mouse model of gestational hypertension was established using homocysteine. As demonstrated in Fig. 4A, hypertension was decreased by Candesartan treatment compared with the control. Plasma concentrations of VCE and $\alpha$-ADR were also downregulated by Candesartan treatment compared with the control, as determined by RT-qPCR (Fig. 4B and C).
Candesartan treatment also upregulated NF- $\kappa \mathrm{B}$ activation and nuclear translocation in vivo (Fig. 4D and E). Immunostaining assays revealed that $\mathrm{p} 65$, IKK- $\beta$ and I $\mathrm{B} \alpha$ expression levels in vascular endothelial cells were increased after 14-day treatment with Candesartan (Fig. 4F). In addition, ELISA assays demonstrated that Candesartan treatment significantly inhibited aldosterone (Fig. 4G) and renin (Fig. 4H) release in serum in mice with gestational hypertension. Taken together, these results suggested that Candesartan treatment may be beneficial for the treatment of gestational hypertension induced by homocysteine.

\section{Discussion}

Reports have indicated angiotensin release and Ang-IITR expression serve a crucial role in the initiation and development of gestational hypertension, which respectively target angiotensin and $\alpha$-ADR $(28,29)$. Research also suggests that VCE and $\alpha$-ADR are potential targets for the treatment of gestational hypertension (30). The underlying mechanism of formation of gestational arterial hypertension for women during pregnancy have been investigated and results have indicated that Ang-IITR contributes to the progression of gestational hypertension (31). Therefore, Ang-IITR may be a potential target and studies have revealed the efficacy of an Ang-IITR antagonist for hypertension in the clinic (32-34). In the present study, the therapeutic effects of Candesartan (an Ang-IITR antagonist) was investigated in pregnant mice with hypertension, which was induced by homocysteine. Although various previous studies have investigated the efficacy of Candesartan for the treatment of hypertension, the therapeutic effects of Candesartan for gestational hypertension is infrequently reported $(35,36)$.

Candesartan is in a class of drugs called angiotensin II receptor antagonists. Candesartan prevents the constriction (narrowing) of veins and arteries and has been used in the treatment of essential hypertension (37). Currently, the classical RAS has been studied extensively for decades and has yielded numerous effective therapies for gestational hypertension and gestational hypertension-induced complications $(19,38)$. Research has indicated that Ang-IITR blockers are antihypertensive drugs that may be an efficient way to improve the renin-angiotensin system by binding to Ang-IITR, leading to improvement of RAS, gestational hypertension and gestational hypertension-associated target organ damage in hypertensive animal models (39-41). Therefore, the present study determined whether Candesartan may have therapeutic effects on gestational hypertension. Candesartan treatment markedly improved gestational hypertension in a mouse model of gestational hypertension induced by homocysteine. The findings of the present study have suggested that Candesartan improves gestational hypertension via the $\mathrm{NF}-\kappa \mathrm{B}$ signaling pathway.

Previous studies revealed that the $N F-\kappa B$ signaling pathway may be involved in the biochemical metabolism of vascular endothelial cells and progression of gestational hypertension (42,43). Henke et al (44) demonstrated that vascular endothelial cell-specific NF- $\mathrm{NB}$ inhibition not only attenuates hypertension, but may also improve hypertension-induced renal damage. Alonso et al (45) revealed that an angiotensin IIand NF- $\mathrm{B}$-dependent mechanism may increase connexin 43 in murine arteries by targeting of renin-dependent 
A

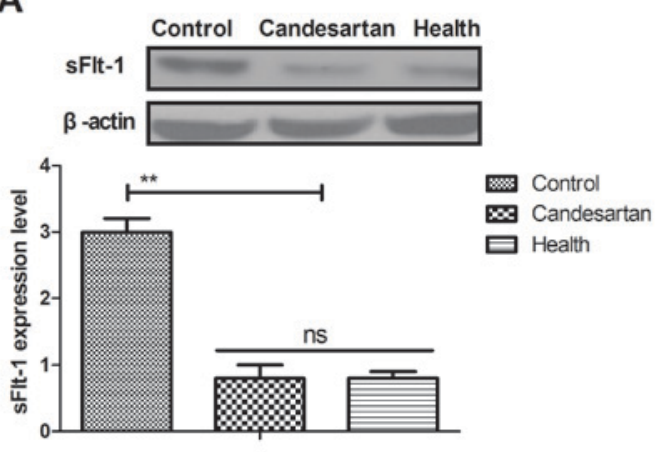

\section{C}

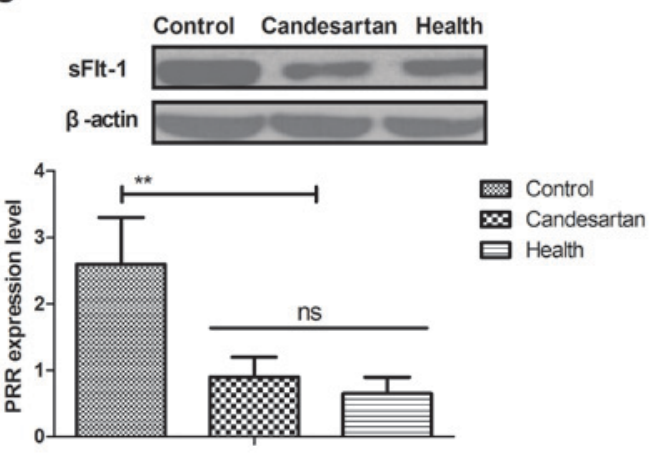

E
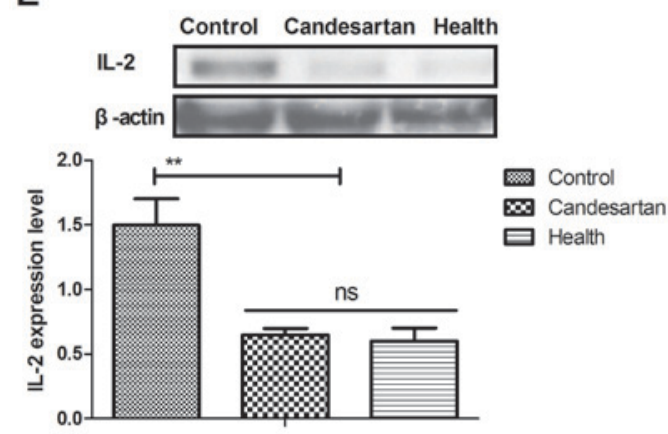

G

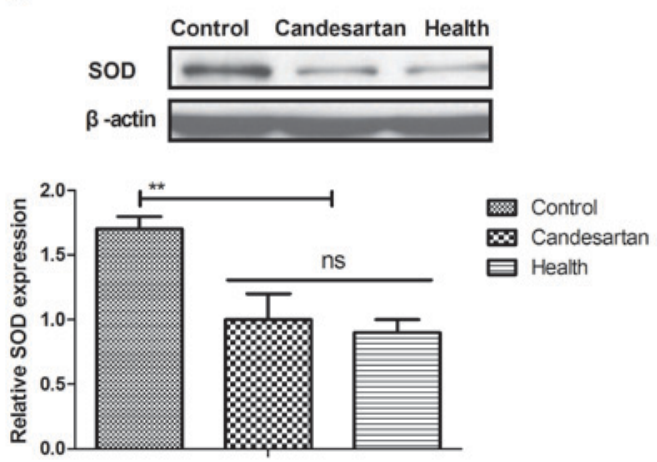

B

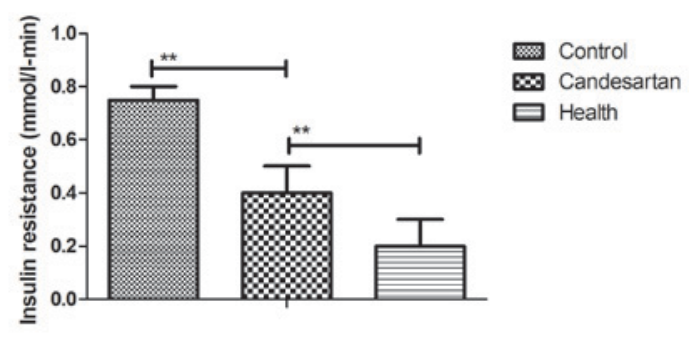

D

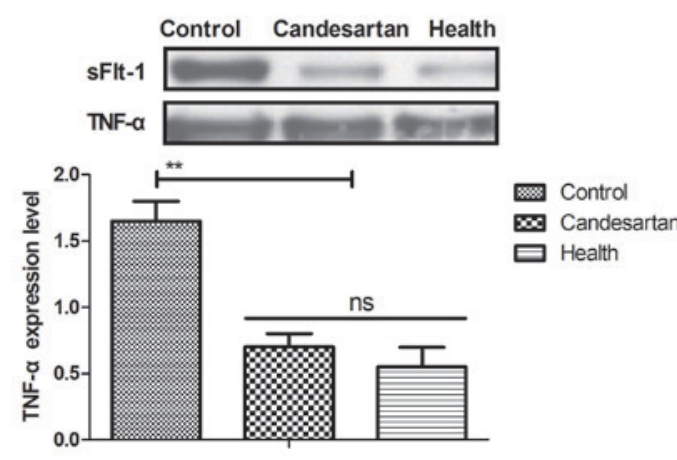

$\mathbf{F}$

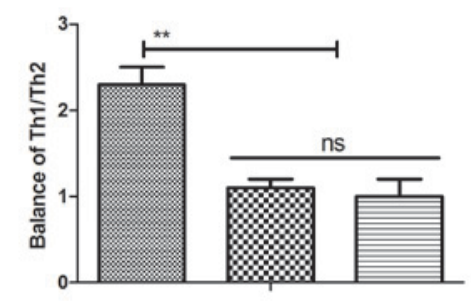

Control

$\infty$ Candesartan

曰 Health

H
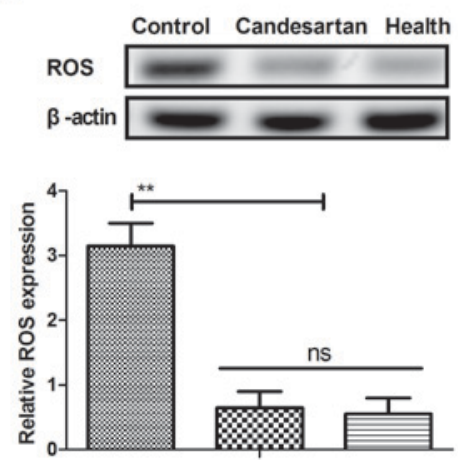

‥ Control

$\infty$ Candesartan

$\square$ Health

Figure 2. Analysis of sFlt-1, insulin resistance and cardiovascular risk factors in mice with gestational hypertension after treatment with Candesartan. (A) Expression levels of sFlt-1 in control, healthy or Candesartan-treated vascular endothelial cells. (B) Insulin resistance of control, healthy or Candesartan-treated mice with gestational hypertension. (C) Expression levels of PRR in control, healthy or Candesartan-treated vascular endothelial cells. Expression levels of (D) TNF- $\alpha$ and (E) IL-2, and (F) balance of Th1/Th2 in the serum of control, healthy or Candesartan-treated mice with gestational hypertension. Expression levels of (G) SOD and (H) ROS in control, healthy or Candesartan-treated vascular endothelial cells. The data are presented as the mean \pm standard error. ${ }^{* *} \mathrm{P}<0.01$ vs. control. ns, no significant difference. sFlt-1, soluble fms-like tyrosine kinase 1 ; PRR, prorenin receptor; TNF- $\alpha$, tumor necrosis factor- $\alpha$; IL-2, interleukin-2; Th1, T-helper cell class 1; Th2, T-helper cell class 2; SOD, superoxide dismutase; ROS, reactive oxygen species.

hypertension. In addition, the NF- $\mathrm{kB}$ signaling pathway may be involved in obesity-induced hypertension (46). The
$\mathrm{NF}-\mathrm{\kappa B}$ pathway is also involved in C-reactive protein-induced effects on pulmonary arterial endothelial cells in chronic 
A

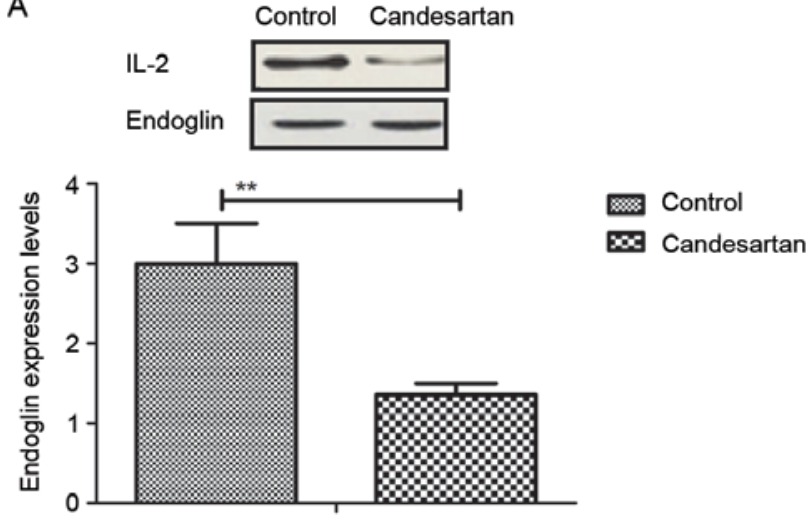

C

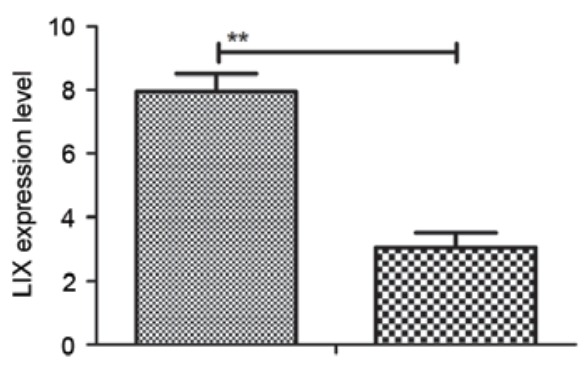

E

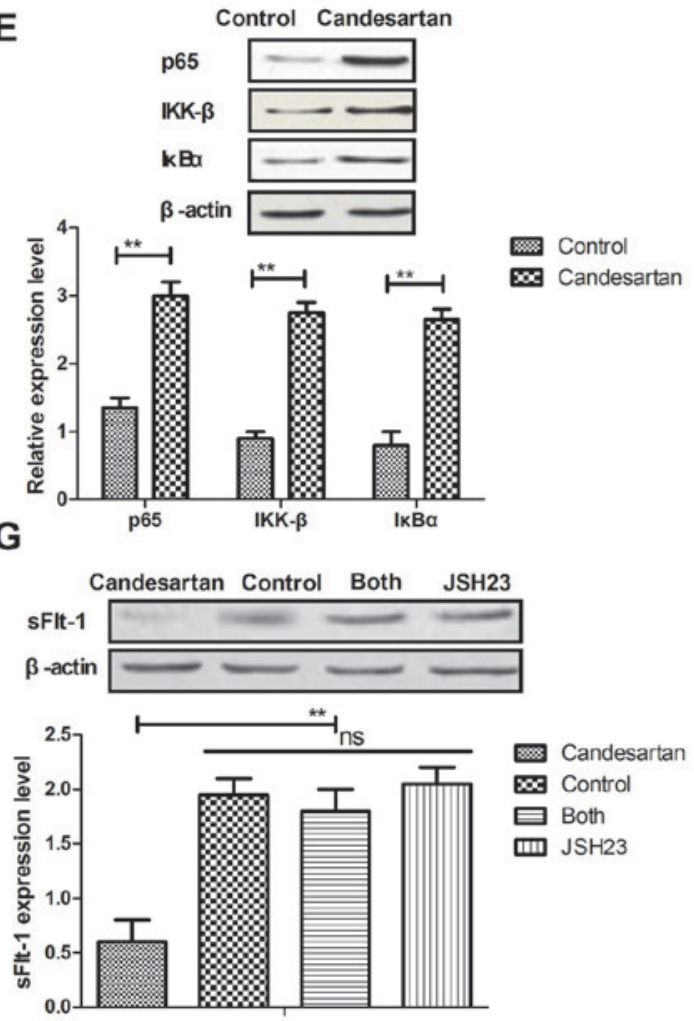

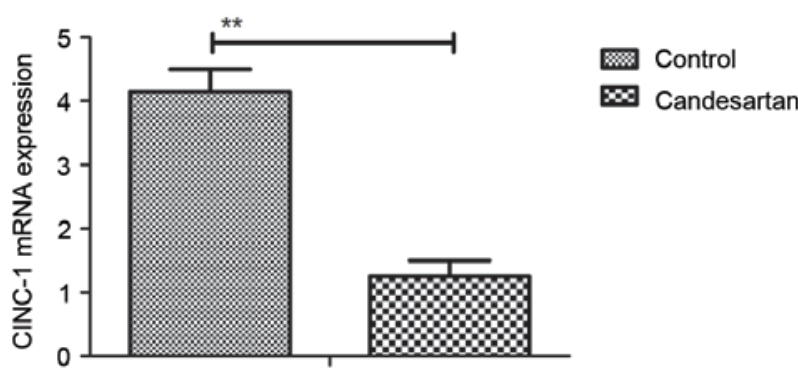

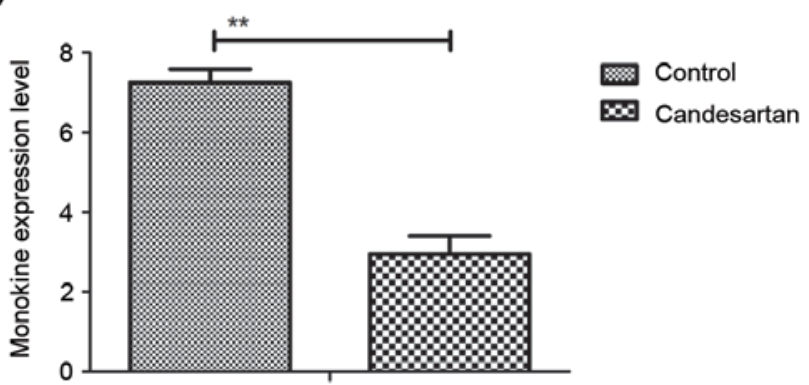

$\mathbf{F}$

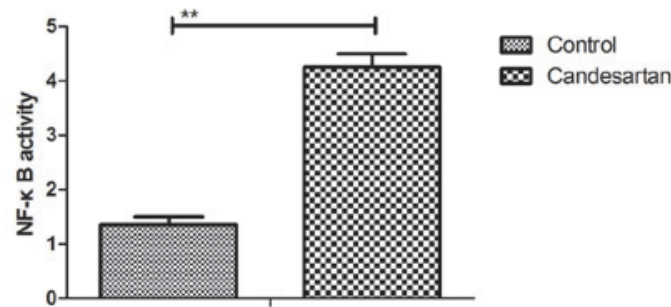

$\mathrm{H}$
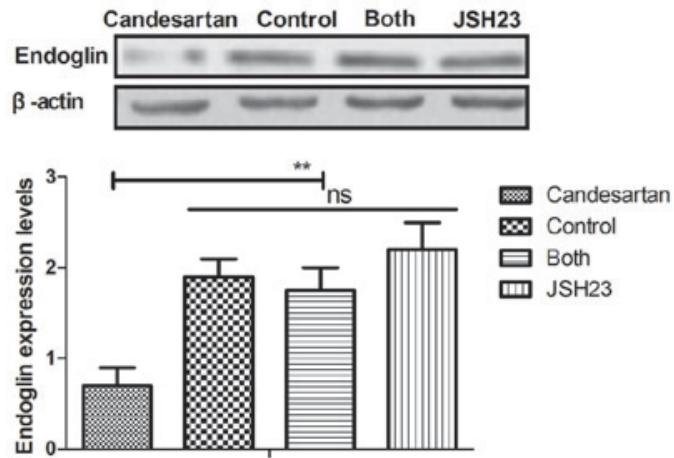

Figure 3. Candesartan regulates gestational hypertension via the NF- $\kappa$ B signaling pathway. (A) Expression levels of endoglin in control or Candesartan-treated vascular endothelial cells. mRNA expression levels of (B) CINC-1, (C) LIX and (D) monokine in control or Candesartan-treated vascular endothelial cells.

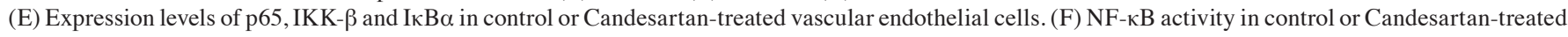
vascular endothelial cells. Inhibition of NF-kB activity by JSH23 reversed Candesartan-mediated reduction of (G) sFlt-1 and (H) endoglin expression levels. The data are presented as the mean \pm standard error. ${ }^{* *} \mathrm{P}<0.01$ vs. control. NF- $\mathrm{\kappa B}$, nuclear factor- $\mathrm{k}$; $\mathrm{CINC}-1$, cytokine-induced neutrophil chemoattractant

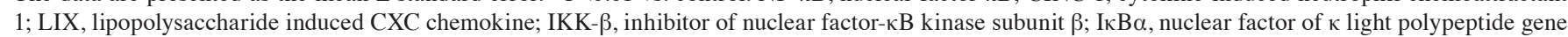
enhancer in B-cells inhibitor $\alpha$; sFlt-1, soluble fms-like tyrosine kinase.

thromboembolic pulmonary hypertension. Furthermore, the effect of antihypertensive drugs on the expression of $\mathrm{NF}-\kappa \mathrm{B}$ in monocrotaline-induced pulmonary arterial hypertension of rats have been investigated by Li et al (47). These reports 
A

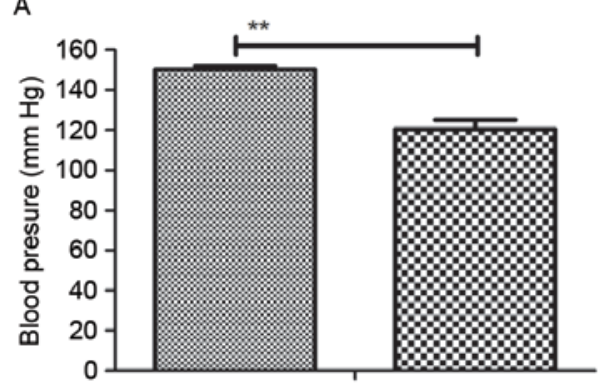

C

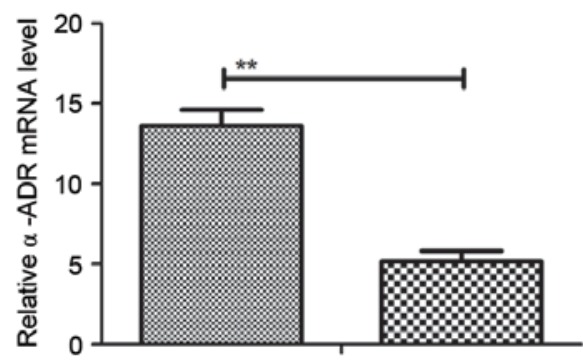

E

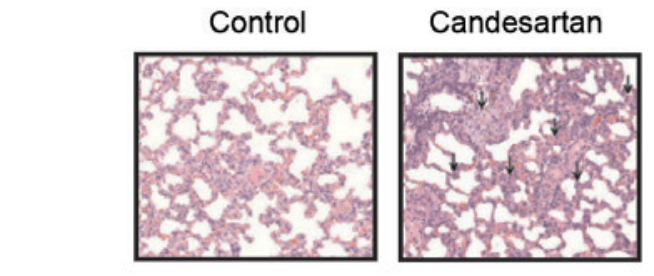

Control

Candesartan

G
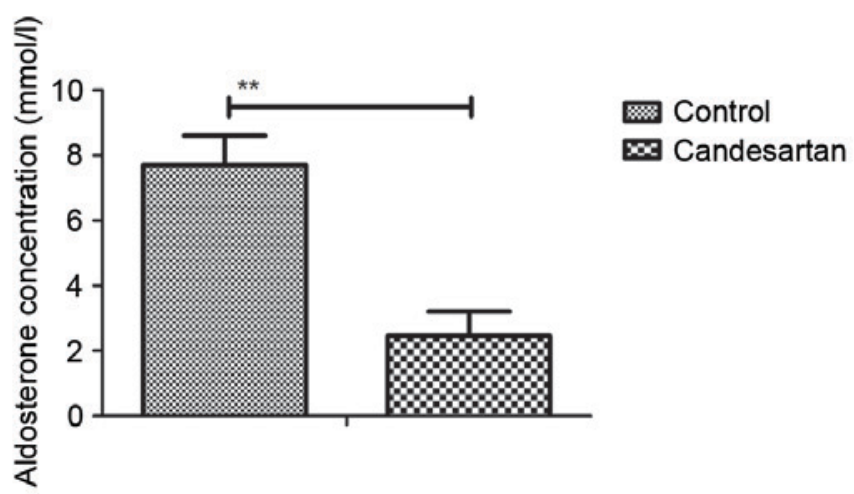

B

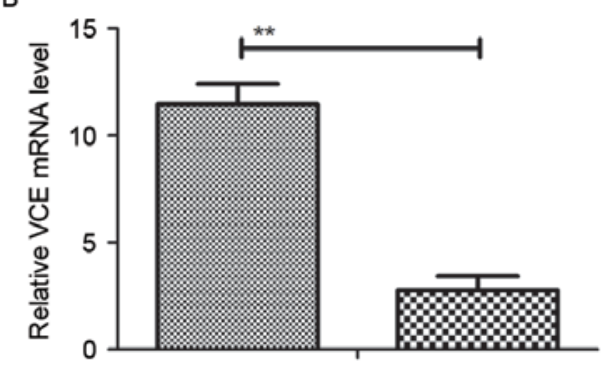

D

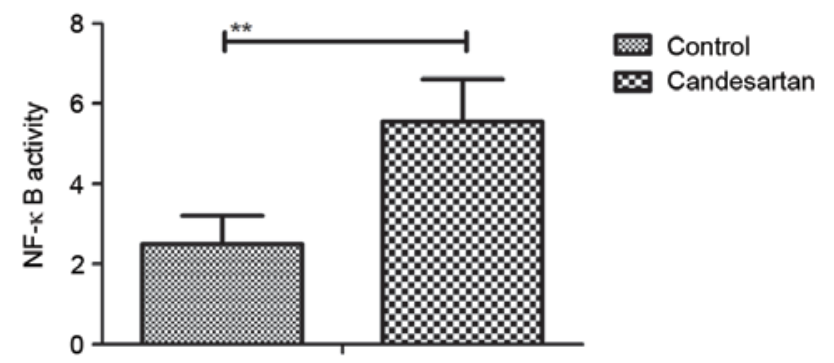

$\mathrm{F}$

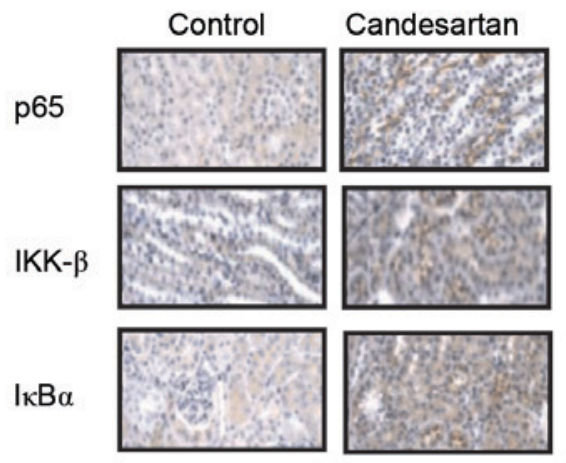

$\mathrm{H}$

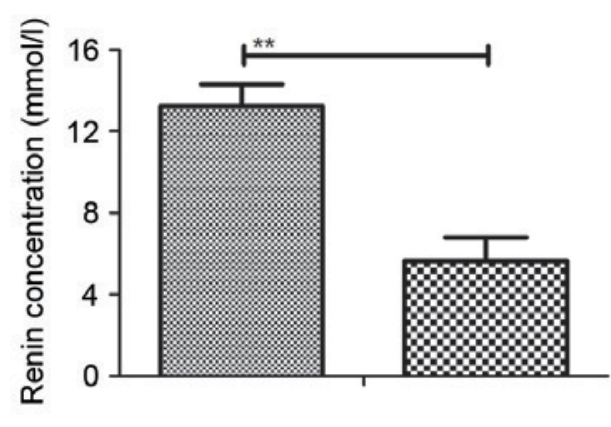

Control

Figure 4. In vivo therapeutic effects of Candesartan on mice with gestational hypertension induced by homocysteine. (A) Blood pressure was reduced after Candesartan treatment, suggesting an improvement in gestational hypertension compared with the control. Plasma concentration levels of (B) VCE and (C) $\alpha$-ADR in control or Candesartan-treated mice with gestational hypertension. (D) NF-kB activity and (E) nuclear translocation of NF-kB were analyzed in control or Candesartan-treated vascular endothelial cells. (F) Immunostaining for p65, IKK- $\beta$ and IкB $\alpha$ expression levels in control or Candesartan-treated vascular endothelial cells. ELISA assays analyze concentration levels of $(\mathrm{G})$ aldosterone and $(\mathrm{H})$ renin release in serum in control or Candesartan-treated mice with gestational hypertension. The data are presented as the mean \pm standard error. ${ }^{* *} \mathrm{P}<0.01$ vs. control. VCE, vasodilation converting enzyme; $\alpha$-ADR,

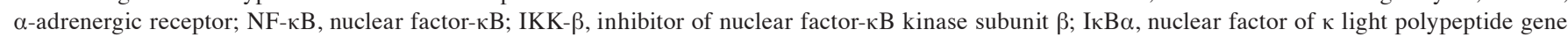
enhancer in B-cells inhibitor $\alpha$.

suggested that the NF- $\mathrm{B}$ signaling pathway may be associated with the initiation and progression of hypertension.

The results of the present study suggested that the NF- $\kappa \mathrm{B}$ signaling pathway influences Candesartan-mediated soluble endoglin and cytokine (CINC-1, LIX and monokine) expressions levels in vascular endothelial cells. Blocking of the $\mathrm{NF}-\kappa \mathrm{B}$ signaling pathway suppressed Candesartan-mediated improvement of sFlt-1 and endoglin expression levels. sFlt-1 
and endoglin are two important predictive biomarkers of gestational hypertension $(48,49)$. Alterations in sFlt-1 and endoglin expression levels may predict the progression of gestational hypertension $(50,51)$. The results of the present study suggested that sFlt-1 and endoglin expression levels are altered after Candesartan treatment. Notably, gestational hypertension is markedly decreased after Candesartan treatment once daily for a total of 14 days.

To conclude, the present study investigated the clinical efficacy of Candesartan in mice with gestational hypertension induced by homocysteine. Although previous studies have reported the direct effects of Candesartan on hypertension, the present study investigated the effects of Candesartan in gestational hypertension and gestational hypertension-associated factors $(52,53)$. This study suggested that Candesartan has a novel role in gestational hypertension management and an increasing number of preclinical reports show promising results (54-56). Of note, our results suggested that the NF- $\kappa$ B signaling pathway is involved in Candesartan-mediated initiation and progression of gestational hypertension. Overall, our findings suggested that mice with gestational hypertension treated by Candesartan exhibited beneficial effects for inflammation, oxidative stress and hypertension. However, future work should be performed in a larger cohort to support the data of the present study.

\section{Acknowledgements}

Not applicable.

\section{Funding}

No funding was received.

\section{Availability of data and materials}

The analyzed data sets generated during the study are available from the corresponding author on reasonable request.

\section{Author's contributions}

$\mathrm{XZ}$ performed the experiments. XW designed the experiments and analyzed the data.

\section{Ethics approval and consent to participate}

The present study was carried out in strict accordance with the recommendations in the Guide for Shandong Provincial Hospital affiliated to Shandong University. All surgery and euthanasia were performed to minimize suffering. This study was approved by the ethics committee of Shangdong University and Taian City Central Hospital (Jinan, China).

\section{Consent for publication}

Not applicable.

\section{Competing interests}

The authors declare that they have no competing interests.

\section{References}

1. Kennedy DA, Woodland C and Koren G: Lead exposure, gestational hypertension and pre-eclampsia: A systematic review of cause and effect. J Obstet Gynaecol 32: 512-517, 2012.

2. Huang YH, Chen YP, Liang CC, Chang YL and Hsieh CC: Impetigo herpetiformis with gestational hypertension: A case report and literature review. Dermatology 222: 221-224, 2011.

3. Mohamad Razi ZR and Schindler AE: Review on role of progestogen (dydrogesterone) in the prevention of gestational hypertension. Horm Mol Biol Clin Investig 27: 73-76, 2016.

4. Pengo MF, Rossi GP and Steier J: Obstructive sleep apnea, gestational hypertension and preeclampsia: A review of the literature. Curr Opin Pulm Med 20: 588-594, 2014.

5. Zhu YC, Sun Y and Yang HX: Chronic hypertension superimposed on preeclampsia at 13 gestational weeks: A case report with review. Chin Med J(Engl) 125: 2067-2069, 2012.

6. Grandone E, Margaglione M, Colaizzo D, Cappucci G, Sciannamé N, Montanaro S, Paladini D, Martinelli P and Di Minno G: Prothrombotic genetic risk factors and the occurrence of gestational hypertension with or without proteinuria. Thromb Haemost 81: 349-352, 1999.

7. Vasapollo B, Novelli GP, Gagliardi G, Tiralongo GM, Pisani I, Manfellotto D, Giannini L and Valensise H: Medical treatment of early-onset mild gestational hypertension reduces total peripheral vascular resistance and influences maternal and fetal complications. Ultrasound Obstet Gynecol 40: 325-331, 2012

8. Banhidy F, Acs N, Puho EH and Czeizel AE: The efficacy of antihypertensive treatment in pregnant women with chronic and gestational hypertension: A population-based study. Hypertens Res 33: 460-466, 2010.

9. Schoenaker DA, Soedamah-Muthu SS and Mishra GD: The association between dietary factors and gestational hypertension and pre-eclampsia: A systematic review and meta-analysis of observational studies. BMC Med 12: 157, 2014.

10. Zainul Rashid MR, Lim JF, Nawawi NH, Luqman M, Zolkeplai MF, Rangkuty HS, Mohamad Nor NA, Tamil A, Shah SA, Tham SW and Schindler AE: A pilot study to determine whether progestogen supplementation using dydrogesterone during the first trimester will reduce the incidence of gestational hypertension in primigravidae. Gynecol Endocrinol 30: 217-220, 2014.

11. Wang YA, Chughtai AA, Farquhar CM, Pollock W, Lui K and Sullivan EA: Increased incidence of gestational hypertension and preeclampsia after assisted reproductive technology treatment. Fertil Steril 105: 920-926 e922, 2016.

12. Hua X, Zhang J, Guo Y, Shen M, Gaudet L, Janoudi G, Walker M and Wen SW: Effect of folic acid supplementation during pregnancy on gestational hypertension/preeclampsia: A systematic review and meta-analysis. Hypertens Pregnancy 35: 447-460, 2016.

13. Basaran A, Basaran M, Topatan B and Martin JN Jr: Effect of chorionic villus sampling on the occurrence of preeclampsia and gestational hypertension: An updated systematic review and meta-analysis. J Turk Ger Gynecol Assoc 17: 65-72, 2016.

14. Chinnathambi V, More AS, Hankins GD, Yallampalli C and Sathishkumar K: Gestational exposure to elevated testosterone levels induces hypertension via heightened vascular angiotensin II type 1 receptor signaling in rats. Biol Reprod 91: 6, 2014

15. Seremak-Mrozikiewicz A,Drews K, Chmara E, Mrozikiewicz PM and Slomko Z: Gestational hypertension $(\mathrm{GH})$ and a1166c polymorphism of angiotensin II type 1 receptor. Ginekol Pol 71: 783-788, 2000 (In Polish).

16. Chen PM, Lai TS, Chen PY, Lai CF, Wu V, Chiang WC, Chen YM, Wu KD and Tsai TJ: Renoprotective effect of combining pentoxifylline with angiotensin-converting enzyme inhibitor or angiotensin II receptor blocker in advanced chronic kidney disease. J Formos Med Assoc 113: 219-226, 2014.

17. Mavrakanas TA, Gariani K and Martin PY: Mineralocorticoid receptor blockade in addition to angiotensin converting enzyme inhibitor or angiotensin II receptor blocker treatment: An emerging paradigm in diabetic nephropathy: A systematic review. Eur J Intern Med 25: 173-176, 2014.

18. Tsutamoto T, Nishiyama K, Yamaji M, Kawahara C, Fujii M, Yamamoto T and Horie M: Comparison of the long-term effects of candesartan and olmesartan on plasma angiotensin II and left ventricular mass index in patients with hypertension. Hypertens Res 33: 118-122, 2010. 
19. Kjeldsen SE, Stålhammar J, Hasvold P, Bodegard J, Olsson U and Russell D: Effects of losartan vs candesartan in reducing cardiovascular events in the primary treatment of hypertension. J Hum Hypertens 24: 263-273, 2010.

20. Fogari R, Zoppi A, Salvadeo SA, Mugellini A, Lazzari P, Santoro T and Derosa G: Fibrinolysis and insulin sensitivity in imidapril and candesartan (FISIC study) recipients with hypertension. Hypertens Res 34: 509-515, 2011.

21. Nishida Y, Takahashi Y, Nakayama T, Soma M, Kitamura N and Asai S: Effect of candesartan monotherapy on lipid metabolism in patients with hypertension: A retrospective longitudinal survey using data from electronic medical records. Cardiovasc Diabetol 9: 38, 2010.

22. Wai-Hoe L, Wing-Seng L, Ismail Z and Lay-Harn G: SDS-PAGE-Based quantitative assay for screening of kidney stone disease. Biol Proced Online 11: 145-160, 2009.

23. Armstrong DW, Tse MY, O'Tierney-Ginn PF, Wong PG, Ventura NM, Janzen-Pang JJ, Matangi MF, Johri AM, Croy BA, Adams MA and Pang SC: Gestational hypertension in atrial natriuretic peptide knockout mice and the developmental origins of salt-sensitivity and cardiac hypertrophy. Regul Pept 186: 108-115, 2013.

24. Partyka R, Chmiel B, Sikora J, Grabowska T, Wróbel B, Praisner A, Pióro A, Jałowieicki P and Kokocinska D: Lipofuscin, homocysteine and tissue polypeptide specific antigen in gestational hypertension. Neuro Endocrinol Lett 28: 311-314, 2007.

25. Xiao S, Wang J and Xiao N: MicroRNAs as noninvasive biomarkers in bladder cancer detection: A diagnostic meta-analysis based on qRT-PCR data. Int J Biol Markers 31: e276-e285, 2016.

26. Livak KJ and Schmittgen TD: Analysis of relative gene expression data using real-time quantitative PCR and the 2(-Delta Delta C(T)) method. Methods 25: 402-408, 2001.

27. Yang L, Zhang W, Zhang L, Zhang S, Yang Y, Wang Q, Shao J, Chen $\mathrm{G}$ and Wang Y: Gestational hypertension risk evaluation based on epidemiological, biochemical, and hemodynamic factors. Clin Exp Obstet Gynecol 40: 61-65, 2013.

28. Van Guilder GP, Pretorius M, Luther JM, Byrd JB, Hill K, Gainer JV and Brown NJ: Bradykinin type 2 receptor BE1 genotype influences bradykinin-dependent vasodilation during angiotensin-converting enzyme inhibition. Hypertension 51: 454-459, 2008.

29. Iwatsubo $\mathrm{K}$ and Umemura S: Alpha adrenergic receptor blockers for patients with hypertension. Nihon Rinsho 64 (Suppl 6) S294-S299, 2006 (In Japanese).

30. Mancia G: Introduction to a compendium on hypertension. Circ Res 116: 923-924, 2015.

31. Davidovich IM, Bloshchinskaia IA and Petrichko TA: Gestational arterial hypertension. Mechanisms of formation. Treatment with normodipin. Ter Arkh 75: 50-54, 2003 (In Russian).

32. Kong J and Li YC: Effect of ANG II type I receptor antagonist and ACE inhibitor on vitamin D receptor-null mice. Am J Physiol Regul Integr Comp Physiol 285: R255-R261, 2003.

33. Hagiwara S, Iwasaka H, Hidaka S, Hasegawa A, Koga H and Noguchi T: Antagonist of the type-1 ANG II receptor prevents against LPS-induced septic shock in rats. Intensive Care Med 35: 1471-1478, 2009.

34. Rakusan K, Chvojkova Z, Oliviero P, Ostadalova I, Kolar F, Chassagne C, Samuel JL and Ostadal B: ANG II type 1 receptor antagonist irbesartan inhibits coronary angiogenesis stimulated by chronic intermittent hypoxia in neonatal rats. Am J Physiol Heart Circ Physiol 292: H1237-H1244, 2007.

35. Yasuno S, Fujimoto A, Nakagawa Y,Kuwahara K and Ueshima K: Fixed-dose combination therapy of candesartan cilexetil and amlodipine besilate for the treatment of hypertension in Japan. Expert Rev Cardiovasc Ther 10: 577-583, 2012.

36. Barrios V and Escobar C: Candesartan in the treatment of hypertension: What have we learnt in the last decade? Expert Opin Drug Saf 10: 957-968, 2011.

37. Kwon BJ, Jang SW, Choi KY, Kim DB, Cho EJ, Ihm SH, Youn HJ and Kim JH: Comparison of the efficacy between hydrochlorothiazide and chlorthalidone on central aortic pressure when added on to candesartan in treatment-naive patients of hypertension. Hypertens Res 36: 79-84, 2013.

38. Henriksson M, Russell D, Bodegard J, Kjeldsen S, Hasvold P, Stålhammar J and Levin LÅ: Health-care costs of losartan and candesartan in the primary treatment of hypertension. J Hum Hypertens 25: 130-136, 2011.
39. Moltzer E, Mattace Raso FU, Karamermer Y, Boersma E, Webb GD, Simoons ML, Danser AH, van den Meiracker AH and Roos-Hesselink JW: Comparison of candesartan versus metoprolol for treatment of systemic hypertension after repaired aortic coarctation. Am J Cardiol 105: 217-222, 2010.

40. Meredith PA, Murray LS and McInnes GT: Comparison of the efficacy of candesartan and losartan: A meta-analysis of trials in the treatment of hypertension. J Hum Hypertens 24: 525-531, 2010.

41. Ogihara T, Nakao K, Fukui T, Fukiyama K, Fujimoto A, Ueshima K, Oba K, Shimamoto K, Matsuoka H and Saruta T; CASE-J Trial Group: The optimal target blood pressure for antihypertensive treatment in Japanese elderly patients with high-risk hypertension: A subanalysis of the candesartan antihypertensive survival evaluation in Japan (CASE-J) trial. Hypertens Res 31: 1595-1601, 2008.

42. Gu JW, Tian N, Shparago M, Tan W, Bailey AP and Manning RD Jr: Renal NF-kappaB activation and TNF-alpha upregulation correlate with salt-sensitive hypertension in Dahl salt-sensitive rats. Am J Physiol Regul Integr Comp Physiol 291: R1817-R1824, 2006.

43. Ortiz LA, Champion HC, Lasky JA, Gambelli F, Gozal E, Hoyle GW, Beasley MB, Hyman AL, Friedman $M$ and Kadowitz PJ: Enalapril protects mice from pulmonary hypertension by inhibiting TNF-mediated activation of NF-kappaB and AP-1. Am J Physiol Lung Cell Mol Physiol 282: L1209-L1221, 2002.

44. Henke N, Schmidt-Ullrich R, Dechend R, Park JK, Qadri F, Wellner M, Obst M, Gross V, Dietz R, Luft FC, et al: Vascular endothelial cell-specific NF-kappaB suppression attenuates hypertension-induced renal damage. Circ Res 101: 268-276, 2007.

45. Alonso F, Krattinger N, Mazzolai L, Simon A, Waeber G, Meda P and Haefliger JA: An angiotensin II- and NF-kappaB-dependent mechanism increases connexin 43 in murine arteries targeted by renin-dependent hypertension. Cardiovasc Res 87: 166-176, 2010.

46. Purkayastha S, Zhang G and Cai D: Uncoupling the mechanisms of obesity and hypertension by targeting hypothalamic IKK- $\beta$ and NFKB. Nat Med 17: 883-887, 2011.

47. Li XW, Guo B, Shen YY and Yang JR: Effect of chrysin on expression of NOX4 and NF-kappaB in right ventricle of monocrotaline-induced pulmonary arterial hypertension of rats. Yao Xue Xue Bao 50: 1128-1134, 2015 (In Chinese).

48. Carney EF: Hypertension: sFlt-1 removal seems to be beneficial in women with pre-eclampsia. Nat Rev Nephrol 11: 690, 2015.

49. Valbuena-Diez AC, Blanco FJ, Oujo B, Langa C, Gonzalez-Nuñez M, Llano E, Pendas AM, Díaz M, Castrillo A, Lopez-Novoa JM and Bernabeu C: Oxysterol-induced soluble endoglin release and its involvement in hypertension. Circulation 126: 2612-2624, 2012.

50. Daly AL, Robertson A, Johnson P, Middleton S, Bobek G, Sullivan C and Hennessy A: PP162. sFlt-1 controlled by CPAP in a pregnant patient with chronic hypertension. Pregnancy Hypertens 2: 327, 2012.

51. Gluchowska M, Kowalska-Koprek U and Karowicz-Bilińska A: Evaluation of the usefulness of endoglin level as a predictor of preeclampsia in pregnant women with hypertension. Ginekol Pol 84: 835-840, 2013 (In Polish).

52. Muda P, Kampus P, Teesalu R, Zilmer K, Ristimäe T, Fischer K and Zilmer M: Effects of amlodipine and candesartan on oxidized LDL level in patients with mild to moderate essential hypertension. Blood Press 15: 313-318, 2006.

53. Ikeda $\mathrm{H}$, Inoue $\mathrm{T}$, Uemura $\mathrm{S}$, Kaibara R, Tanaka $\mathrm{H}$ and Node $\mathrm{K}$ : Effects of candesartan for middle-aged and elderly women with hypertension and menopausal-like symptoms. Hypertens Res 29: 1007-1012, 2006.

54. Nzelu D, Dumitrascu-Biris D, Hunt KF, Cordina M and Kametas NA: Pregnancy outcomes in women with previous gestational hypertension: A cohort study to guide counselling and management. Pregnancy Hypertens, 2017.

55. Pauli JM, Lauring JR, Stetter CM, Repke JT, Botti JJ, Ural SH and Ambrose A: Management of gestational hypertension-the impact of HYPITATa. J Perinat Med 41: 415-420, 2013.

56. Sibai BM: Management of late preterm and early-term pregnancies complicated by mild gestational hypertension/pre-eclampsia. Semin Perinatol 35: 292-296, 2011.

This work is licensed under a Creative Commons Attribution-NonCommercial-NoDerivatives 4.0 International (CC BY-NC-ND 4.0) License. 